\title{
Effect of Speed Screw Press Extruder on the Grain Capacity and Sensory Properties of Monggomas Analog Rice
}

\author{
*Bernatal Saragih \\ Department of Agricultural Product \\ Technology, Faculty of Agriculture \\ Mulawarman University \\ Samarinda, Indonesia \\ *email: saragih_bernatal@yahoo.com
}

\author{
Almasih Isa \\ Department of Agricultural Product \\ Technology, Faculty of Agriculture \\ Mulawarman University \\ Samarinda, Indonesia \\ email: almasihisa95@gmail.com
}

\author{
Hudaida Syahrumsah \\ Department of Agricultural Product \\ Technology, Faculty of Agriculture \\ Mulawarman University \\ Samarinda, Indonesia \\ email:syahrumsyah_ida@yahoo.com
}

\begin{abstract}
Redesign the analog rice printing machines is one of the efforts to provide alternative printing machines. The name Monggomas was derived from the basic ingredients of analog rice made by researchers namely mocaf (mo), bonggol pisang (nggo)/banana hump, mayas (mas)/mayas rice. The purpose of this research was to make an analog rice printing machine and to know the proper screw rotation speed of the printing process analog rice. This study used a complete randomized design with 4 levels of treatment. Comparison of screw rotation speed is 60, 50, 40 and $30 \mathrm{rpm}$ (rotary per minute). The data obtained were analyzed with ANOVA. The parameters observed were grain capacity, hedonic test and hedonic quality test. The results showed variations in rotary screw speed significantly affected the texture and uniformity of rice analog with the best treatment was the speed of $30 \mathrm{rpm}$. Results of the hedonic test of texture and uniformity in rice cooked was like, while the color and aroma were rather like. The hedonic quality of texture and uniformity is solid, with a white brown color and a slightly aromatic of banana hump. The hedonic test texture of cooked rice is like, color and aroma. The hedonic quality test of cooked rice, soft texture, whitebrown color and slightly flavorful of banana hump. The hedonic quality of color, aroma and taste tends to be influenced by the composition of rice.
\end{abstract}

Keywords: screw press, rotary, analog rice, capacity, sensory

\section{INTRODUCTION}

The need for rice is increasing every year along with increasing population. Indonesian is the highest rice consumption countries in Asia and for the previous three years as the highest rice consumption country in the world. Processed products from non-rice carbohydrate sources developed lately are analog rice. Analog rice is made from non-rice with carbohydrate content close to or exceeding rice made from local flour or rice flour $(3,6)$. Analog rice is artificial rice made only from local non-rice flour (2). This research is an advanced research comparing mocaf flour (Mo); banana hump/bonggol pisang (nggo): mayas rice (Mas), abbreviated with monggomas. This continiue research makes and tests a tool with analog rice formulations that have been determined in previous studies (6). One key to diversifying the product of an extrusion product lies in the die, where the material will be pushed out. Die in making pasta increases the diversity of its use in producing products with various forms, water content, and consistency in shape uniformity $(9,10)$.

\section{RESEARCH METHODS}

\section{A. Time and Place}

This research was carried out for 7 months, from the end of August 2018 to March 2019 and this research was done at Djokro brothers workshop Samarinda and processing laboratory and quality control of agricultural products, Mulawarman University, Samarinda.

\section{B. Materials and Tools}

Materials used namely mocaf flour, banana hump, mayas rice and glycerol mono stearate (GMS). Extruder machine components are stainless steel (type 304), iron plate (type 304), gearbox (WPA brand trans gear), dynamo (ryota), axle (type 304), van-belt (A24-Bando \& A38Mitsuboshi), pully (Al), stainless steel cylindrical tubes (type 304). The tools used in this research are welding equipment, lathe (CY6250Bx2000), drill (bosch), grinder (bosch).

\section{Manufacture of Extruder Machine}

To determine of the best of rotation is done by large pully size method with $1450 \mathrm{rpm}$ dynamo suspension and 15: 1 gearbox rotation were performed resulting from the reduction between dynamo and gearbox that is $96 \mathrm{rpm}$ then divided by the size of the pully size $5,6,7$ and 8 inchi, accumulated in treatment and produces a rotation of $60 \mathrm{rpm}$ to $30 \mathrm{rpm}$, a minimum capacity of 500 grams of input ingredients for the dough on a single screw press extruder.

\section{Analog Rice Processing on Extruder Machine}

Analog rice samples used are rice produced from an extruder machine. The experimental design used in this study was to analyze a more efficient machine design carried out by designing synchronously to produce the right speed and pressure rice grains. The test sample was divided into 4 with 3 times replications, namely: 60, 50, 40 and 30 $\mathrm{rpm}$. The formulation of analog rice consist of mocaf, banana hump flour and mayas flour (80: 2: 18), vegetable 
oil $30 \mathrm{~mL}$ and GMS as much as 5 grams. The mixture is stirred for 5 minutes and then steaming at $85^{\circ} \mathrm{C}$ for 10 minutes. Dought after steam put into the extruder by a series of processes, rice granules are then dried in an oven with temperature $70^{\circ} \mathrm{C}$ for 3 hours.

\section{E. Sensory Test}

The hedonic scale test (preference) in this rice and cooked rice study uses 5 rating scales with rather trained panelists, amounting to 20 people. Hedonic quality (Table I) test was done by giving a score 5 rating scales for attributing the color, aroma, texture and uniformity. Hedonic scale test values 1-5 (very dislike, dislike, rather like, like, like very much).

TABLE I. HEDONIC QUALITY

\begin{tabular}{|l|l|}
\hline $\begin{array}{c}\text { Hedonic } \\
\text { quality }\end{array}$ & \multicolumn{1}{|c|}{ Scale } \\
\hline Color & 1=blackish white \\
\hline & 2=brownish white \\
\hline & 3=bone white \\
\hline & 4=white \\
\hline Aroma & 5=bright white \\
\hline & 1=very scented stubby flour banana \\
\hline & 3=not flavorful banana weevil flour \\
\hline & 4=flavorful banana hump flour and mocaf \\
\hline & $\begin{array}{l}\text { 5=very flavorful mocaf flour and banana } \\
\text { hump }\end{array}$ \\
\hline Texture & 1=very not solid \\
\hline & 2=not solid \\
\hline & 3=solid \\
\hline & 4=rather dense \\
\hline & 5=very solid \\
\hline Uniformity & 1=uniform broken grain shape \\
\hline & 2=partially broken grain shape \\
\hline & 3=non whole grain shape \\
\hline & 4=somewhat whole grain shape \\
\hline & 5=whole grain shape \\
\hline &
\end{tabular}

\section{F. Data Analysis}

The data obtained was analyzed with ANOVA; if the test had a significant effect on the treatment, it was then continued with the Least Significant Difference test at $\alpha=0.05$.

\section{RESULT AND DISCUSSION}

\section{A. Thread Turning Speed and Extruder Machine Capacity}

The best rotation speed based on texture and uniformity is obtained in treatment 4 with a speed of $30 \mathrm{rpm}$ (Table II).
TABLE II. AVERAGE TEST RESULTS OF THE SCREW ROTATION SPEED.

\begin{tabular}{|c|c|c|c|}
\hline Treatment & $\begin{array}{c}\text { Dinamo speed } \\
\text { drive }(\mathbf{r p m}) / \\
\text { with pully }\end{array}$ & $\begin{array}{c}\text { Speed } \\
\text { thread } \\
(\mathbf{r p m})\end{array}$ & $\begin{array}{c}\text { Capacity } \\
\text { grains/minutes }\end{array}$ \\
\hline K1 & $1450 / 5$ inchi & 60 & 32,400 \\
\hline K2 & $1450 / 6$ inchi & 50 & 27,000 \\
\hline K3 & $1450 / 7$ inchi & 40 & 21,600 \\
\hline K4 & $1450 / 8$ inchi & 30 & 16,200 \\
\hline
\end{tabular}

The advantage is the slower rotation of the screw pressure on the material increases so that the level of hardness is better, but the grain capacity obtained is less compared to more speed faster, faster rotation causes less compact texture.

Increased extruder screw speed results in an increase in the rate of extrudate expansion (1), the degree of expansion increases due to increased screw speed, but a further increase in extruder screw speed does not cause changes in the degree of extrudate expansion (8).

\section{B. Capacity Extruder Machine}

From the test results it can be seen that the effective capacity shows the maximum output at a level of certain operation. In general, the effective capacity is lower than the design capacity. Extruder machine capacity is obtained by taking analog rice product weight data every 1 minute. The minimum capacity of this extruder is $1 \mathrm{~kg}$ with an engine speed of $60 \mathrm{~kg} /$ hour. The cutting speed of the cutting blade and the size of the product can be adjusted accordingly. In the experiment, the treatment used was $30 \mathrm{rpm}$. This experiment is carried out to find the process parameters in the extrusion machine so that it can form the product according to the mold. The capacity (mass flow rate) of a single screw extruder is related to the screw rotational speed, thread size and characteristics of the screw (5). Desirable characteristics (high expansion, low bulk density, and hardness) for chickpea were obtained at high exit-die temperature, relatively high moisture, and high screw speed (7).

\section{Rice Sensories Properties}

The average hedonic test results and hedonic quality of monggomas analog rice (Table III).

TABLE III. AVERAGE HEDONIC TEST RESULTS AND HEDONIC QUALITY OF ANALOG MONGGOMAS RICE WITH SCREW ROTATION SPEED TREATMENT

\begin{tabular}{|c|l|c|c|c|c|}
\hline \multirow{2}{*}{$\begin{array}{c}\text { Sensory } \\
\text { Properties }\end{array}$} & \multicolumn{4}{|c|}{ Treatment (rpm) } \\
\cline { 2 - 6 } & $\mathbf{3 0}$ & $\mathbf{4 0}$ & $\mathbf{5 0}$ & $\mathbf{6 0}$ \\
\hline \multirow{3}{*}{$\begin{array}{l}\text { Hed } \\
\text { onic }\end{array}$} & Color & $3.20 \pm 0.03$ & $3.22 \pm 0.16$ & $3.27 \pm 0.19$ & $3.38 \pm 0.06$ \\
\cline { 2 - 6 } & Aroma & $3.97 \pm 0.19$ & $4.02 \pm 0.03$ & $4.04 \pm 0.06$ & $4.05 \pm 0.16$ \\
\cline { 2 - 6 } & Texture & $3.62 \pm 0.01 \mathrm{c}$ & $3.69 \pm 0.17 \mathrm{bc}$ & $3.84 \pm 0.07 \mathrm{ab}$ & $4.05 \pm 0.13 \mathrm{a}$ \\
\cline { 2 - 6 } & $\begin{array}{l}\text { Uniform } \\
\text { ity }\end{array}$ & $3.47 \pm 0.07 \mathrm{~b}$ & $3.61 \pm 0.18 \mathrm{~b}$ & $3.61 \pm 0.13 \mathrm{ab}$ & $3.91 \pm 0.18 \mathrm{a}$ \\
\hline \multirow{2}{*}{$\begin{array}{l}\text { Hed } \\
\text { onic } \\
\text { qual } \\
\text { ity }\end{array}$} & Color & $2.63 \pm 0.14$ & $2.71 \pm 0.13$ & $2.70 \pm 0.06$ & $2.73 \pm 0.09$ \\
\cline { 2 - 6 } & Aroma & $3.93 \pm 0.09$ & $3.98 \pm 0.19$ & $4.01 \pm 0.07$ & $4.15 \pm 0.13$ \\
\cline { 2 - 6 } & Texture & $3.29 \pm 0.06 \mathrm{c}$ & $3.45 \pm 0.09 \mathrm{bc}$ & $3.60 \pm 0.17 \mathrm{~b}$ & $3.93 \pm 0.25 \mathrm{a}$ \\
\cline { 2 - 6 } & $\begin{array}{l}\text { Uniform } \\
\text { ity }\end{array}$ & $3.35 \pm 0.08 \mathrm{c}$ & $3.45 \pm 0.06 \mathrm{bc}$ & $3.63 \pm 0.08 \mathrm{ab}$ & $3.83 \pm 0.20 \mathrm{a}$ \\
\hline
\end{tabular}


Note: Numbers followed by the same letter on the same line show no significant difference at the level $\alpha=0.05$

The rice sensory test (Table III) shows that all samples have no significant effect on the color hedonic scale, the aroma with the score rather likes, while the texture and uniformity scale have a significant effect with the score rather like to like. The results of ANOVA show that the average value of panelists' likes and dislikes on the color and aroma of analog rice on the variation of the rotation speed of the screw for all treatments does not significantly affect the score rather like the hedonic test and hedonic quality of rice, then on the texture and uniformity for all treatments have a significant effect. For the highest level of preference given by the panelists in the hedonic test of rice texture, there was a treatment at $60 \mathrm{rpm}(4.05 \pm 0.13 \mathrm{a})$ with a like score (Table 2).

Analog rice making involves mixing the ingredients namely mocaf flour and rice flour then adding water from total weight with the aim of adding water content to facilitate the process of pragelatinization (3). Analog rice can be produced using various methods and types of flour $(2,4)$. Analog rice for artificial rice from tubers, cereals, and sago by using extrusion technology (2).

\section{Rice Sensories After Cooked}

The average hedonic test results and hedonic quality of monggomas analog rice after cooked describe in Table IV.

TABLE IV. AVERAGE HEDONIC TEST RESULTS AND HEDONIC QUALITY OF ANALOG MONGGOMAS RICE COOKED WITH SCREW ROTATION SPEED TREATMENT

\begin{tabular}{|c|c|c|c|c|c|}
\hline \multirow{2}{*}{\multicolumn{2}{|c|}{$\begin{array}{l}\text { Sen sory } \\
\text { properties }\end{array}$}} & \multicolumn{4}{|c|}{ Treatment (rpm) } \\
\hline & & \multirow{2}{*}{$\begin{array}{c}\mathbf{3 0} \\
3.64 \pm 0,20\end{array}$} & \multirow{2}{*}{$\frac{40}{3.70 \pm 0.15}$} & \multirow{2}{*}{$\frac{\mathbf{5 0}}{3.76 \pm 0.25}$} & \multirow{2}{*}{$\begin{array}{c}\mathbf{6 0} \\
3.81 \pm 0.25\end{array}$} \\
\hline \multirow{4}{*}{$\begin{array}{l}\text { Hedo } \\
\text { nic }\end{array}$} & Color & & & & \\
\hline & Aroma & $3.88 \pm 0.20$ & $3.93 \pm 0.03$ & $3.97 \pm 0.00$ & $3.99 \pm 0.20$ \\
\hline & Texture & $3.05 \pm 0.04 \mathrm{c}$ & $\begin{array}{r}3.25 \pm 0.28 \mathrm{~b} \\
\mathrm{c}\end{array}$ & $3.44 \pm 0.08 b$ & $3.92 \pm 0.14 \mathrm{a}$ \\
\hline & $\begin{array}{l}\text { Unifor } \\
\text { mity }\end{array}$ & $3.48 \pm 0.11$ & $3.50 \pm 0.22$ & $3.62 \pm 0.22$ & $3.76 \pm 0.35$ \\
\hline \multirow{4}{*}{$\begin{array}{l}\text { Hedo } \\
\text { nic } \\
\text { quali } \\
\text { ty }\end{array}$} & Color & $2.94 \pm 0.21$ & $2.97 \pm 0.18$ & $2.95 \pm 0.06$ & $3.00 \pm 0.16$ \\
\hline & Aroma & $2.69 \pm 0.06$ & $2.70 \pm 0.17$ & $2.71 \pm 0.10$ & $2.84 \pm 0.09$ \\
\hline & Texture & $3.22 \pm 0.07 \mathrm{c}$ & $\begin{array}{r}3.45 \pm 0.11 \mathrm{~b} \\
\mathrm{c}\end{array}$ & $3.61 \pm 0.22 b$ & $4.07 \pm 0.04 \mathrm{a}$ \\
\hline & $\begin{array}{l}\text { Unifor } \\
\text { mity }\end{array}$ & $3.49 \pm 0.22$ & $3.46 \pm 0.16$ & $3.48 \pm 0.05$ & $3.51 \pm 0.25$ \\
\hline
\end{tabular}

Note: Numbers followed by the same letter on the same line show no significant difference at the level $\alpha=0.05$

The rice cooked sensory test results Table 3 shows that all samples have no significant effect on the color, aroma and taste scale with a slightly like score, while the texture scale has a significant effect with a score of somewhat like to like. The results of variance shows that the average value of panelists' likes and dislikes on the color, aroma and taste of analog rice on the variation of the rotation speed of the screw has no significant effect with the score rather like the hedonic test and the hedonic quality of the rice, then the texture has a significant effect. For the highest preference level value that was given by panelists in the hedonic quality test of rice texture, it was found in the treatment of $60 \mathrm{rpm}$ $(4.07 \pm 0.04 \mathrm{a})$. The screw speed and temperature have a negative effect on hardness so raising the extruder screw speed will reduce the product hardness value (9), steam time treatment has an influence on the yield of analog rice (6).

\section{CONCLUSION}

Increased extruder screw speed results in an increase in the rate of extrudate expansion and grain capacity. The best treatment with a screw rotation speed of $30 \mathrm{rpm}$. Texture and uniformity were favored by panelists approaching rice. The effect of screw rotation speed has significant effect on hedonic and hedonic quality of texture and uniformity of monggomas analog rice.

\section{ACKNOWLEDGMENT}

Thank you to the Islamic Development Bank and Mulawarman University for funding this research

\section{REFERENCES}

[1] Baik BK, Powers J, Nguyen LT. Extrusion of regular and waxy barley flours for production of expanded cereal. Journal of cereal chemistry. 2004. 81(1): 94-99.

[2] Budijanto S, Yuliyanti. Study of preparation of sorghum flour (Sorghum bicolor l.moench) and its application in making analog rice. Jurnal Teknologi Pertanian. 2012. 13(3):177-186.

[3] Samad, MY. Making Artificial Rice (Artificial Rice) with Raw Material of Cassava and Sago. Journal of Science and Technology BPPT VII.IB.0. 2003.

[4] Herawati $\mathrm{H}$, Widowati S. Characteristics of mutiara rice from sweet potatoes (Ipomea batatas). Buletin Teknologi Pascapanen Pertanian. 2009.5:37-44

[5] Karwe MV. Food Extrusion, Food Engineering Vol. III. Cook College, Rutgers University. New jersey USA.1992.

[6] Saragih B, Sari DN and Rahmadi A. The effect of steaming duration on nutrition composition, glycemic index and load of analog rice from natural products East Kalimantan. International Journal of Recent Scientific Research. $2019.10 \quad$ (02):31072-31075. DOI:http://dx.doi.org/10.24327/ijrsr.2019.1002.3186

[7] Yovchev A, Stone A, Hood-niefer S, Nickerson. Influence of the extrusion parameter on the physical properties of chikpea and barley extrudates. Food science and biotechnology. 2017. 26(2):393-399. doi 10.1007/s10068-017-0054-x

[8] Schmid AH, Dolan KD, Ng PKW. Effect of extruding wheat flour at lower temperatures on physical attributes of extrudates and on thiamin loss when using carbon dioxide gas as a puffing agent. Journal of Cereal Chem. 2005.82(3): 305-313.

[9] Tripalo B, ZAEK JDI, Semenski D, Dravar NN, Ukrainczyk M. Effect of twin-screw extrusion parameter on mechanical hardness of direct-expanded extrudates. Sadhan. 2006.31(5): 527-536.

[10] Navale SA, Swami SB and N.J. Thakor. Extrusion Cooking Technology for Foods: A Reviw. Journal of Ready to Eat Food. 2015.2(3): 66-80 